International Journal of Linguistics, Literature and Translation

ISSN: 2617-0299 (Online); ISSN: 2708-0099 (Print)

DOI: $10.32996 / \mathrm{ijllt}$

Journal Homepage: www.al-kindipublisher.com/index.php/ijltt

IJLLT

\title{
Developing Students' Translation Competence: The Role of Tasks and Teaching Activities
}

\author{
Habiba Nakhli \\ EFL teacher and Ph.D. Candidate, Linguistics, Communication and Translation, University Abdelmalek Essaadi, Tetouan, Morocco.
}

$\square$ Corresponding Author: Habiba Nakhli, E-mail: habibanakhli@gmail.com

\section{ARTICLE INFORMATION ABSTRACT}

Received: 11 October 2021

Accepted: 16 November 2021

Published: 30 November 2021

DOI: $10.32996 /$ ijllt.2021.4.11.13

\section{KEYWORDS}

Translation competence, translation teaching, tasks, activities, competence

development
The aim of this study is to identify the teaching procedures generally conducted by translation teachers, and investigate their impact on the development of students' translation competence (TC). The study emphasizes the importance of substituting the traditional "read and translate" method for a student-centered teaching approach that relies on hands-on tasks and engaging activities. These teaching procedures include intra- and extra-mural activities and tasks addressing different sub-competencies and skills and aiming at developing students' general TC. In order to study the impact of these teaching procedures on $\mathrm{TC}$, we implemented a descriptive method that draws upon self-report data and observation of translation teachers and students in a classroom setting. We observed a group of MA translation students in the Faculty of Letters and Humanities in Tetouan and King Fahd School of Translation in TangiersAbdelmalek Essaadi University, Morocco. The observation reports and teachers questionnaires provided significant data about classroom practices, while the survey of students' levels of TC revealed that the respondents' mastery level of TC ranges from low to high across the different sub-competences. We subsequently compared students' mastery levels to the general patterns governing the teachers' teaching procedures, and the findings showed a clear correlation between the two. Accordingly, the type and focus of the tasks and activities performed by students have a direct impact on their TC development.

\section{Introduction}

In the globalization era, the need for competent translators has reached its peak. The translation industry is constantly flourishing and imposing itself as an indispensable means of intercultural communication and information exchange. Translators connect people and cultures from all parts of the world, thus allowing cross-cultural fertilization and evolution. With such a huge responsibility on translators' shoulders, training has become one of the central issues in applied translation studies. The 1970s and 1980 are witnessed the emergence of new teaching approaches inspired by the development in the field of cognitive psychology, applied linguistics, sociolinguistics, and pedagogy. The traditional teaching methods have been replaced by a multitude of modern teaching approaches, which involve hands-on teaching activities, real communication, and authentic tasks aiming at developing students' knowledge and skills.

Clearly, effective translation teaching has to provide the student with operational knowledge and skills that can be transferred to real-life contexts. To this purpose, students should be engaged in purposeful learning activities and tasks that aim at enhancing TC. In this sense, teaching activities and tasks should be "a way of bringing the real world into the classroom" (Krahnke, 1987, p. 57). With regard to the nature of the translation course and its objectives, translation tasks and activities are supposed to mobilize, in addition to linguistic resources, a wide variety of translation strategies and problem-solving skills.

This research investigates the teaching activities and tasks conducted by translation teachers in two MA translation programs in two Moroccan institutions. The aim is to identify the types of activities and tasks conducted by translation teachers and determine their impact on students' TC development.

Copyright: (c) 2021 the Author(s). This article is an open access article distributed under the terms and conditions of the Creative Commons Attribution (CC-BY) 4.0 license (https://creativecommons.org/licenses/by/4.0/). Published by Al-Kindi Centre for Research and Development, London, United Kingdom. 


\section{Literature Review}

\subsection{Translation Competence}

In the field of linguistics, the term competence was introduced by Chomsky (1968), to refer to the unconscious knowledge "that underlies behavior but that is not realized in any direct or simple way in behavior" (p. 4) as opposed to "the actual observed use of language - actual performance"(p.102). The concept was soon introduced to the field of work psychology and human resources development by McClelland (1973) and his notion of professional competence (Albir, 2017). The Competence-Based Education and Training (CBET), widely adopted as a teaching approach nowadays, was first meant to promote the effectiveness of military training in the 1940s and 1950s (Hodge,2007). In the 1970s, the approach was implemented in elementary schools, colleges, universities, teaching programs for adults, and vocational education throughout the USA before reemerging in other parts of the world (Richards \& Rodgers, 2001). Within this framework, competence was no longer limited to an underlying system of knowledge; it encompasses, in addition to knowledge, other assets that make some people outperform others. In other words, more importance was given to the learning output or to learners' ability to demonstrate or make use of what they know in reallife situations.

Lasnier (2001) defines competence as "a complex know-how to act that results from the integration, mobilization, and organization of a set of abilities and skills (which may be cognitive, affective, psychomotor or social) and knowledge (declarative knowledge) used effectively in situations having common characteristics"(p.30)2. Lasnier (2001) distinguishes skills from abilities in terms of complexity. A skill, explains Lasnier, is "a simple know-how, integrating declarative knowledge", whereas ability is "a moderately complex know-how, integrating skills (cognitive, emotional, psychomotor and social) and declarative knowledge (disciplinary content)" (pp. 30-31). Equally, Baartman \& Bruijn (2011) stress the same three constituents of competence "knowledge, skills and attitudes," and suggest that the integration of these elements "should be measured as a learning process and competence as a learning product" (p. 127).

Skills represent a type of procedural knowledge directed to solve a problem in a given situation. They are perceived as domainspecific or goal-oriented "doing or acting in practice" (Baartman \& Bruijn, 2011, p. 127). Knowledge, on the other hand, can be procedural or declarative. Declarative knowledge (Anderson (1983), as cited in Albir, 2017, p.16) refers to the facts, concepts and information acquired or accumulated throughout the process of learning or through a training experience. It can be either general (about the world) or domain-specific (related to a particular discipline). Procedural knowledge, on the other hand, "refers to knowing how to do something without actually acting" (Baartman \& Bruijn, 2011, p. 127). Another type of knowledge is qualified as strategic or meta-cognitive, it pertains to "knowledge about the task, context, problem-solving processes and oneself" (Krathwohl (2002), as cited in Baartman \& Bruijn, 2011, p. 127). Finally, putting skills and knowledge into work depends on attitudes. This term refers to the personal and professional qualities, such as self-motivation, leadership, and values, responsible for enhancing performance in the workplace. Accordingly, we can say that competence is related to quality performance: the higher the skills, knowledge, and attitudes of a person, the greater is his performance.

In the field of translation studies, the first statements on TC, by scholars like Harris and Sherwood (1978), Toury (1980), and Nida (1981), drew on Chomsky's notion on linguistic competence and limit TC to bilingualism. The belief that bilingualism is enough to practice translation confined research to the investigation of how native speakers manage to translate without receiving any formal training. In fact, Harris' notion of 'natural translation' links translation to language acquisition.

In addition to natural aptitude, Toury (1995) stresses the role of social interaction in developing translation skills and maintains that in addition to bilingualism, the translator has "the ability to establish a relationship between the similarities and the differences across languages, which may be termed 'interlingualism' " (Toury 1995, p.248). According to Toury, these capacities differ from one person to another according to their age or mental structures and seem, therefore, to be trainable. His question was then "What is that brings forth the unfolding of the skill (that is its realization in actual behavior) and the way (or ways?) it then develops." 3 (Toury, 1995, p. 246)

The emergence of the communicative-functional approaches to translation, in the 20th century, encouraged the researcher to incorporate extra-linguistic notions like situation, cultural context, and intention and function to their investigations of translation. Accordingly, in addition to communicative competence, researchers integrated professional knowledge, real-world knowledge, assessment, research, and instrumental competencies in their multi-componential TC models (Nord,1991; Neubert, 2000; Beeby, 2000).

2 My translation, emphasis in the original text

3 the writer's Italics 
Clearly, translation is a complex activity that incorporates, in addition to bilingual communicative competence, different types of expertise related to different domains. TC integrates the knowledge, abilities, and attitudes required to handle a translation task ( Albir, 2020). Hence, it cannot be seen as a single skill but as a combination of interdependent sub-competences. According to Albir (2017), competence includes "know (a combination of discipline-specific knowledge), know-how (skills to solve practical problems) and know how to be (skills of a social and affective nature). Finally, one has to bear in mind that competence is only acquired when one is able to use it efficiently in a given context" (p.15). This definition has two important implications for translation teachers. First, to build the desired TC profile in students, it seems necessary to determine the set of skills and abilities in the TC competence spectrum, before addressing it through adequate pedagogical tools. Second, transferability is a crucial characteristic of competence. In other words, competence can be transferred from the school setting to real-life contexts and be adapted to a variety of real-life situations and tasks. A fact that emphasizes the importance of contextualized learning in cultivating TC.

In recent years, inspired by the advances in the field of cognitive psychology, sociology, linguistics, pedagogy, and functional translation theories, more systematic and comprehensive studies were conducted to investigate the components of TC and work out effective methods for its assessment and development. Scholars proposed various multi-componential models of TC (table1). The investigation of TC through longitudinal studies and empirical research provided significant insights on the nature of TC extended to cover, in addition to linguistic competence, an array of skills, knowledge, and abilities that are activated to perform a given translation task. As such, TC differs from a translator to another and can be cultivated through teaching. To guarantee effective TC development, TC sub-components should constitute a framework of reference that determines curriculum design and content as well as the teaching objectives and classroom practices.

Table 1: An overview of translation sub-competencies according to different TC models.

\begin{tabular}{|c|c|c|c|c|}
\hline $\begin{array}{l}\text { Schäffner, } \\
(2000, \text { pp. 146-147) }\end{array}$ & $\begin{array}{l}\text { PACTE(2003) } \\
\text { (Hurtado Albir, 2017, } \\
\text { pp. 39-41) }\end{array}$ & $\begin{array}{l}\text { Kelly, } \\
\text { (2005, pp.32-33) }\end{array}$ & $\begin{array}{l}\text { Kiraly, } \\
(2013,202)\end{array}$ & $\begin{array}{l}\text { Göpferich, (2009, pp. } \\
11-37)\end{array}$ \\
\hline $\begin{array}{l}\text {-linguistic competence } \\
\text { of the languages } \\
\text { concerned } \\
\text {-textual competence }\end{array}$ & $\begin{array}{l}\text {-bilingual sub- } \\
\text { competence }\end{array}$ & $\begin{array}{l}\text { communicative and } \\
\text { textual competence in } \\
\text { at least two languages } \\
\text { and cultures. }\end{array}$ & $\begin{array}{l}\text { linguistic TC } \\
\text {-text typology TC }\end{array}$ & $\begin{array}{l}\text { Communicative } \\
\text { competence in at least } \\
\text { two languages }\end{array}$ \\
\hline $\begin{array}{l}\text { cultural } \\
\text { competence }\end{array}$ & $\begin{array}{l}\text { extra-linguistic sub- } \\
\text { competence }\end{array}$ & $\begin{array}{l}\text { cultural and } \\
\text { intercultural } \\
\text { competence }\end{array}$ & $\begin{array}{l}\text { cultural_TC } \\
\text {-Norms and } \\
\text { conventions TC }\end{array}$ & \\
\hline $\begin{array}{l}\text { domain/subject- } \\
\text { specific competence }\end{array}$ & & $\begin{array}{l}\text { subject area } \\
\text { competence }\end{array}$ & $\begin{array}{l}\text { terminology TC } \\
\text {-world knowledge TC: }\end{array}$ & Domain competence \\
\hline \multirow[t]{4}{*}{$\begin{array}{l}\text {-(re)search } \\
\text { competence }\end{array}$} & $\begin{array}{l}\text { instrumental sub- } \\
\text { competence }\end{array}$ & $\begin{array}{l}\text { professional and } \\
\text { instrumental } \\
\text { competence }\end{array}$ & $\begin{array}{l}\text { research TC } \\
\text {-technology TC }\end{array}$ & $\begin{array}{l}\text { Tools and research } \\
\text { competence }\end{array}$ \\
\hline & $\begin{array}{l}\text { knowledge about } \\
\text { translation sub- } \\
\text { competence }\end{array}$ & $\begin{array}{l}\text { professional and } \\
\text { instrumental } \\
\text { competence }\end{array}$ & $\begin{array}{l}\text { social competences: } \\
\text {-etiquette } \\
\text {-negotiation } \\
\text {-teamwork } \\
\text { personal } \\
\text { competences: } \\
\text {-Autonomy } \\
\text {-preparedness for } \\
\text { lifelong learning } \\
\text {-quality control } \\
\text {-professional } \\
\text { responsibility }\end{array}$ & \\
\hline & $\begin{array}{l}\text { strategic sub- } \\
\text { competence }\end{array}$ & strategic competence & -strategies TC & strategic competence \\
\hline & $\begin{array}{l}\text {-psycho-physiological } \\
\text { components }\end{array}$ & $\begin{array}{l}\text { attitudinal or psycho- } \\
\text { physiological } \\
\text { competence }\end{array}$ & & $\begin{array}{l}\text { Psychomotor } \\
\text { competence }\end{array}$ \\
\hline transfer competence & & $\begin{array}{l}\text { interpersonal } \\
\text { competence }\end{array}$ & & $\begin{array}{l}\text { Translation routine } \\
\text { activation competence }\end{array}$ \\
\hline
\end{tabular}




\subsection{Translation competence development: Tasks and teaching activities}

Within the framework of translator training, Albir (2015) defines tasks as:

a unit of work that is representative of translation practice, intentionally aimed at learning to translate, and designed with a specific objective, a structure, and a work sequence (...). Translation tasks are the cornerstone of teaching unit production and curriculum design in translator training. The acquisition of TC teaching units is organized into different tasks that prepare students for one or more final tasks. Such tasks can be performed in or outside classrooms, with or without guidance, individually or in groups (pairs, teams, etc.). They differ according to the nature of the competence (or indicator) and learning objectives involved. (pp. 263-264)

In her definition, Albir (2015) stresses the correspondence that should exist between tasks, learning objectives, and the targeted competencies. She equally refers to 'projects' or 'open tasks' which encompass a variety of objectives and a greater sequence of units: "Translation projects (with larger-scale final tasks, for example, translating a film) are particularly relevant to specialized subjects" (p. 264).

In like manner, González-Davies(2004), suggests a set of activities, tasks, and projects designed to be implemented in the translation classroom at different stages of the translation process. González-Davies (2004) defines tasks as "a chain of activities with the same global aim and a final product. The full completion of a task usually takes up several sessions. In each of these, the activities lead along the same path towards the same end. On the way, both procedural (know-how) and declarative (know what) knowledge are practiced and explored" (p.23). Thus, putting more emphasis on that tasks are related to the learning process (sequence or organization) and the learning outcome.

González-Davies(2004) distinguishes between tasks and projects: According to her, a project is a "multicompetence assignments that enable the students to engage in pedagogic and professional activities and tasks and work together towards an end product" (p.28). In this context, she draws a distinction between two types of projects: authentic or professional projects and pedagogic projects in terms of outcomes. While professional projects' end product is an authentic translation commission, pedagogic projects mirror real-life translation commissions so as to provide students with skills needed for real-life translation tasks. González-Davies (2004) includes 'activities' as a third learning procedure which she defines as "concrete and brief exercises that help to practice specific points, be they linguistic, encyclopedic, transfer or professional" (p. 22). Practicing speed translation, peer editing, and note-taking are all examples of activities that can be done in a translation classroom.

Based on Albir (2015) and González-Davies(2002) definitions of translation tasks, we can infer the following:

1. Translation tasks generally aim at learning to translate.

2. This objective is split into a sequence of specific objectives or tasks sequence

3. The acquisition of TC is organized and achieved through tasks. Hence, tasks are a core element in curriculum design and organization.

4. Translation tasks fall into different categories: individual tasks, pair tasks, group tasks, guided tasks, and free tasks.

5. Tasks incorporate both procedural and declarative knowledge

6. Tasks are adjusted to the targeted TC (task content, time, and working mode). Different tasks enable the learner to activate different components of competence or one general competence at a time.

7. Projects are a large sequence of tasks leading to one final product and involving interaction between students.

Generally, tasks fall into two major types: assessment or final task, which aims at evaluating learners' performance, and teaching tasks that progressively prepare students for the final task (Albir, 2015). Accordingly, when designing a teaching unit the following criteria should be taken into consideration (Albir, 2015):

1. The unit's function within the chain of teaching units that make up a course,

2. The learning objectives which are related to competence indicators,

3. The competencies to be worked on following a line of progression through various units,

4. The content associated with the competencies addressed,

5. The tasks suggested. For each task, it is necessary to specify the objective to be fulfilled, the instruments to be used, the teaching environment, the task performance guidelines, and the assessment procedure. ( pp.267)

6. Finally, as competencies are accumulative by definition, the teacher needs to segment them into achievable objectives distributed over a sequence of teaching sessions. Successful lessons rely largely on clear objectives, well-designed tasks, and skillful teaching.

Translation tasks should therefore be designed to address specific sub-competences. Similarly, the assessment of learning should be done based on a set of indicators visible in students' performance or behavior. To operationalize PACTE's TC 
model, Albir (2015) distinguishes six categories of competencies for translator training, which must characterize curriculum design and be adapted to each specific pedagogical context and subject:

- Methodological and strategic competencies: applying the methodological principles and strategies necessary to work through the translation process appropriately. They are related to the Strategic and Knowledge of Translation sub-competencies in PACTE's TC model. They also entail the development of certain psycho-physiological components;

- Contrastive competencies: differentiating between the two languages involved, monitoring interference. They are related to the Bilingual sub-competence and are important in the context of introducing students to translation;

- Extra-linguistic competencies: mobilizing encyclopedic, bicultural, and thematic knowledge to solve translation problems. They are related to the Extra-linguistic sub-competence and are important in specialized translation;

- Occupational competencies: operating appropriately in the translation labor market. They are related to the Knowledge of Translation sub-competence (knowledge of aspects of professional practice);

- Instrumental competencies: managing documentary resources and an array of tools to solve translation problems. They are related to the Instrumental sub-competence;

- Translation problem-solving competencies: using appropriate strategies to solve translation problems in different text genres. They entail integrating competencies and psycho-physiological components (Albir, 2015).

Based on this classification of competencies for translator training and the types of tasks and activities suggested by Albir (2015), González-Davies (2002), Nord(2001), and Beeby (1996), we tried to present each category of competencies in terms of their indicators and match them to the corresponding teaching procedures, which address the domain of these competencies ( Table 2). It is worth mentioning that the classification proposed below is not rigid. Translating a given ST, for example, may involve doing research, analyzing cultural references, and using specific translation strategies to solve a translation problem at the same time. Therefore, one task can address a variety of competencies and can accordingly be included under more than one category of competencies.

\begin{tabular}{|c|c|c|}
\hline $\begin{array}{l}\text { Target } \\
\text { Competencies }\end{array}$ & Teaching procedures & Indicators: students should be able to... \\
\hline $\begin{array}{l}\text { Methodologica } \\
\text { I and strategic } \\
\text { competences }\end{array}$ & $\begin{array}{l}\text {-Assign texts to be translated cooperatively } \\
\text { and discussed in the classroom. } \\
\text {-Lecture about translation issues/ theory } \\
\text { (equivalence, untranslatability, strategies....) } \\
\text {-Ask students to keep a translation portfolio } \\
\text { to assess their progression } \\
\text {-Ask students to give presentations. } \\
\text {-Assess students' translation from a } \\
\text { pedagogical perspective }\end{array}$ & $\begin{array}{l}\text {-Justify translation } \\
\text { decisions } \\
\text {-Use meta-language to discuss and assess } \\
\text { translations. } \\
\text {-Use translation strategies to solve translation problems } \\
\text { effectively. } \\
\text {-Apply theoretical knowledge to practice. }\end{array}$ \\
\hline $\begin{array}{l}\text { Occupational } \\
\text { competences }\end{array}$ & $\begin{array}{l}\text {-Assign translations including a potential } \\
\text { initiator, client, reader .... } \\
\text {-Organize seminars with professional } \\
\text { practitioners and with field experts. } \\
\text {-Ask professional translators and field } \\
\text { experts to evaluate the students' work. } \\
\text {-Organize classes in a way that reflects real } \\
\text { professional constraints (by meeting } \\
\text { deadlines and working under time pressure, } \\
\text { simulations...). } \\
\text {-Engage students in authentic translation } \\
\text { projects (for publication, for some } \\
\text { organizations, for community service...) }\end{array}$ & $\begin{array}{l}\text {-Work cooperatively with others to complete a } \\
\text { task. } \\
\text {-Assess others' translations and provide } \\
\text { feedback. } \\
\text {-Revise and edit } \\
\text { translations. } \\
\text {-Undertake an authentic translation task/ project/ } \\
\text { commission (meeting realistic requirements: translation } \\
\text { brief, } \\
\text { deadlines... }\end{array}$ \\
\hline
\end{tabular}




\begin{tabular}{|c|c|c|}
\hline & $\begin{array}{l}\text {-Assess students' translation from a } \\
\text { professional perspective. }\end{array}$ & $\begin{array}{l}\text {-negotiate with clients, plan and manage translation } \\
\text { commissions }\end{array}$ \\
\hline $\begin{array}{l}\text { Extra- } \\
\text { linguistic } \\
\text { competences }\end{array}$ & $\begin{array}{l}\text {-Organize exchange programs /allow } \\
\text { students to take part in exchange programs. } \\
\text {-Ask students to do a comparative analysis of } \\
\text { cultural references in the ST and TT. }\end{array}$ & $\begin{array}{l}\text {-Identify and understand a wide variety of domain- } \\
\text { specific } \\
\text { terminology. } \\
\text {-Understand and produce texts belonging to different } \\
\text { domains. } \\
\text {-Work in a multicultural } \\
\text { context. } \\
\text {-Identify cultural references in the } \\
\text { ST. } \\
\text {-Implement strategies to deal with translation problems } \\
\text { related to cultural } \\
\text { references } \\
\text {-Assess TT acceptability in the target culture }\end{array}$ \\
\hline $\begin{array}{l}\text { Contrastive } \\
\text { competences }\end{array}$ & $\begin{array}{l}\text {-Assign ST analysis (context, text type, } \\
\text { textuality....) } \\
\text {-Ask students to build up field-specific } \\
\text { bilingual glossaries. }\end{array}$ & $\begin{array}{l}\text {-Understand grammatical, lexical, and idiomatic } \\
\text { structures in the } \\
\text { SL. } \\
\text {-Produce grammatical, lexical, and idiomatic structures } \\
\text { in the } \\
\text { TL. } \\
\text {-Identify function markers in } \\
\text { texts. } \\
\text {-Analyze and compare texts belonging to different text } \\
\text { types in the SL and } \\
\text { TL. } \\
\text {-Identify text types and genres conventions and norms } \\
\text { in SL and } \\
\text { TL } \\
\text { - Understand the pragmatic use of typographic } \\
\text { conventions in the SL. }\end{array}$ \\
\hline $\begin{array}{l}\text { Instrumental } \\
\text { competences }\end{array}$ & $\begin{array}{l}\text {-Assign translations involving the use of } \\
\text { specific or multiple --functions in the } \\
\text { computer-aided translation system } \\
\text {-Ask students to do research that involves } \\
\text { consulting different printed and online } \\
\text { resources. }\end{array}$ & $\begin{array}{l}\text {-Use printed resources (dictionaries, encyclopedias, } \\
\text { parallel texts...) } \\
\text { effectively. } \\
\text {-Use CAT (computer-assisted translation) } \\
\text { tools. } \\
\text {-Use online resources (search engines, databases, online } \\
\text { dictionaries, and } \\
\text { encyclopedias...) } \\
\text {-Do documentary research. }\end{array}$ \\
\hline $\begin{array}{l}\text { Problem- } \\
\text { solving } \\
\text { competences }\end{array}$ & $\begin{array}{l}\text {-Engage students in translation tasks that } \\
\text { involve creativity. } \\
\text {-Assign different text types to be translated } \\
\text { at home }\end{array}$ & $\begin{array}{l}\text {-Identify translation problems and } \\
\text { difficulties }\end{array}$ \\
\hline
\end{tabular}




\begin{tabular}{|c|c|c|}
\hline & $\begin{array}{l}\text {-Do focused activities/ tasks (on cohesion, } \\
\text { grammatical equivalence, cultural references, } \\
\text { translation strategies...) }\end{array}$ & $\begin{array}{l}\text {-Implement appropriate strategies and skills to solve } \\
\text { translation } \\
\text { problem } \\
\text {-Organize, plan and carry out a translation task } \\
\text { appropriately } \\
\text {-Utilize various problem solving strategies } \\
\text {-Read efficiently, write and } \\
\text { type } \\
\text {-Think logically and draw accurate conclusions/ } \\
\text { Analyze and synthesize } \\
\text { ideas } \\
\text {-Demonstrate creativity and innovation when solving } \\
\text { problems }\end{array}$ \\
\hline
\end{tabular}

Table 2: Competences and their corresponding tasks and mastery indicators.

\section{Methodology}

With regard to the thesis aim and the nature of the subject matter, a descriptive method is adopted in this research. As the research starts from the hypothesis that translation teachers conduct different tasks to improve students' TC and guarantee their engagement in learning, the descriptive method is expected to provide detailed information and adequate descriptions of the activities and processes understudy with the aim of finding correspondences between teachers' teaching procedures and students' levels of TC.

\subsection{Research instruments}

\subsubsection{The observation}

For the purpose of this research, non-participant observation was conducted over a period of four weeks. The classes proceeded in their natural conditions and the different stages, procedures, and interactions that took place were recorded in the observation grid. The observation sessions were preceded and followed by focused meetings. In the pre-observation meetings, the teachers provided information about their students' level, and number, the session's content and objectives, and the teaching material they used. In the post-observation meetings, the teachers were willing to provide clarifications about the procedures they followed.

\subsubsection{The questionnaires:}

-Students' questionnaire contains a set of 34 closed questions. The respondent is asked to select the category that best describes his answer. The set of abilities was formulated based on the TC categories mentioned before (Albir, 2015). Each element refers to a specific ability and the respondent ticks the answer that corresponds to his mastery level in this ability.

-Teachers' questionnaire aims at exploring the frequency of different teaching procedures generally conducted by the respondents and specifies their rate of frequency.

\subsubsection{Research Sample:}

The method of purposive sampling was used to select the sample of the present research. The sample is made of teachers and students of translation who are selected based on their direct relationship with the subject matter.

-The sample of teachers includes six experienced teachers who have long work experience in the field of translation teaching. The participants have therefore the necessary knowledge and understanding of the subject matter to provide the required information.

-The students' sample consists of 58 participants. Participants are currently studying translation in MA programs at University Abdelmalek Essaadi in Tetouan (UAE) or at Ecole Supérieure Roi Fahd de Traduction (ESRFT) in Tangiers.

\section{Results and Discussion}

An integrative reading of the results obtained from the questionnaires and the observation sessions led to the following findings: 
1- $\quad$ Students show different levels of mastery in each sub-competence:

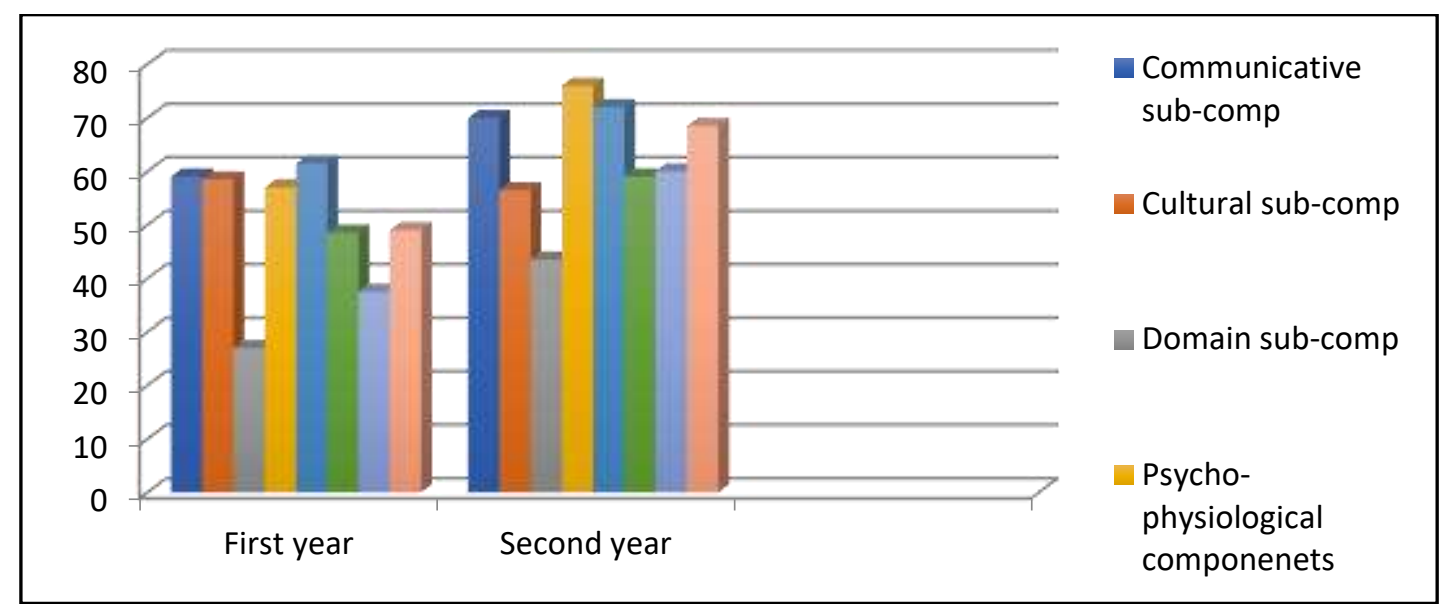

\section{Chart 1: Students level of mastery in the different translation sub-competences}

2- $\quad$ The surveyed translation teachers use a variety of teaching procedures addressing different aspects of translation competence. However, it is worth noting that not all competencies are addressed equally. Based on the frequency of tasks, we conclude that some competencies are more frequently addressed compared to others. The most frequent tasks are the translation of texts and lecturing about theoretical issues followed by focused tasks, while the least frequent kind of tasks are those involving the use of CAT tools

3- Relating these general tendencies to students' levels of competence reveals a correlation between the levels of competence reported by students and the frequency of corresponding teaching procedures. The table below (Table 3 ) presents examples of tasks, the abilities addressed by these tasks, and the corresponding percentages of students with high competence. The first part of the chart presents examples of frequent tasks while the second part presents a set of less frequent tasks. It is noticeable that the percentages of students with high competence levels are higher in competencies that are frequently addressed through tasks and activities. This fact emphasizes the direct role of tasks and activities in developing TC.

\begin{tabular}{|c|c|c|c|}
\hline Teaching procedures & $\begin{array}{l}\text { Related } \\
\text { Competences }\end{array}$ & Abilities developed & $\begin{array}{l}\text { Percentages of students with } \\
\text { high competence level }\end{array}$ \\
\hline \multirow[t]{2}{*}{$\begin{array}{l}\text { assigning texts to be } \\
\text { translated at home }\end{array}$} & \multirow[t]{2}{*}{$\begin{array}{c}\text { Strategic, } \\
\text { Problem solving }\end{array}$} & $\begin{array}{l}\text {-Utilize different problem- } \\
\text { solving strategies }\end{array}$ & $57 \%$ \\
\hline & & $\begin{array}{l}\text {-Organize, plan and carry out } \\
\text { a translation task }\end{array}$ & $64 \%$ \\
\hline $\begin{array}{l}\text { research } \text { work that } \\
\text { involves } \\
\text { different printed and } \\
\text { online resources }\end{array}$ & Instrumental & $\begin{array}{lll}\text { Use } & \text { different } & \text { printed } \\
\text { resources } & & \end{array}$ & $84 \%$ \\
\hline ST analysis & Contrastive & Identify text type conventions & $78 \%$ \\
\hline $\begin{array}{l}\text { Assign group } \\
\text { translations followed by } \\
\text { discussions }\end{array}$ & Occupational & $\begin{array}{l}\text { Use meta-language to discuss } \\
\text { and comment on the translation }\end{array}$ & $41 \%$ \\
\hline
\end{tabular}




\begin{tabular}{|l|c|c|c|}
\hline $\begin{array}{l}\text { Engaging students in } \\
\text { authentic translation } \\
\text { projects. }\end{array}$ & Occupational & $\begin{array}{c}\text { Undertaking } \\
\text { translation tasks }\end{array}$ & $52 \%$ \\
\hline $\begin{array}{l}\text { tasks involving the use } \\
\text { of CAT tools }\end{array}$ & Instrumental & Using CAT tools effectively & $53 \%$ \\
\hline
\end{tabular}

\section{Table (3): The relationship between teaching procedures and students' level of competence.}

1. Based on the observation reports, the use of authentic and situated tasks, involving collaboration, professional communicative skills, and work management, remains limited. This means that translation competence is addressed by teachers from a holistic view that incorporates various aspects of the overall translation competence instead of dealing with each component individually through focused tasks. Nevertheless, teaching and learning professional skills do not necessarily occur in a classroom setting. As students are required to spend training periods in a translation services office, they are supposed to acquire more professional skills in a real-life context.

2. It is not always possible for the teacher to achieve his objectives. Among the factors that constitute a real challenge are the number of students and time constraints as addressing students' individual needs and different learning styles becomes impossible. Another challenge that faces teachers is that some students lack the necessary motivation to improve their performance. In addition, some students lack mastery of linguistic skills and have limited general knowledge, which hinders the acquisition of other competencies.

3. Based on the observation reports, in addition to the teaching procedures, teachers use different teaching strategies to keep students engaged. These include providing immediate positive feedback and encouraging students to comment and exchange feedback among themselves.

4. Other strategies used by teachers comprise using an interactive working mode instead of lecturing and engaging students in cooperative work. These strategies can improve students' ability to do teamwork and develop their interpersonal skills.

5. Planning is another feature that characterizes a teacher's work and facilitates the learning-teaching process. Making students aware of the teaching objectives, using preparatory tasks to orient students' attention, activating and building on students' prior knowledge, pre-teaching new concepts, and moving from simple to more complicated tasks are all structured measures that help reach the teaching objectives.

\section{Conclusion}

Teaching translation is not only a matter of expertise or knowledge. Effective teaching takes place when expertise and knowledge are transformed into teaching practices that boost student performance. To this end, teaching activities and tasks should be designed in a way that serves the teaching objectives and engages learners in meaningful learning. Given the nature of the translation course and its objectives, translation tasks and activities are supposed to incorporate a wide variety of translation strategies and procedures, problem-solving and working tools related to different situations.

This research aims at investigating the teaching activities and tasks generally conducted by translation teachers in Morocco and their impact on the development of students' TC. Although TC development can be better investigated and described through longitudinal research and experimental methods, the present descriptive study achieved its aim by providing considerable findings of the different teaching procedures and their effect on TC development.

Due to the multi-dimensional nature of TC, a multitude of teaching procedures are implemented by teachers to cover all its aspects and components. It has been noted that these procedures have a direct impact on the level of student's competence. However, some sub-competencies cannot be fully addressed through classroom activities and tasks as their development requires more time and effort. Among these, we can mention domain and bicultural competencies for instance. Additionally, competence development is an ongoing process, taking place through lifelong learning, we cannot neglect the influence of other factors such as informal education and work/training experience.

It is equally worth noting that the teaching outcomes are not only influenced by the teaching procedures but by the overall teaching approach. Adapting a learner-centered approach where students are interactively engaged in tasks seems to be more motivating and therefore more effective. The reason is that students feel more confident and motivated when they are learning by doing and experiencing. The mediating role performed by the teacher is yet crucial in providing feedback, selecting material, planning the teaching stages, and providing a positive learning atmosphere. 
Another factor influencing TC development is the use of authentic tasks and materials. Using authentic tasks and material is not only motivating for students it also and most importantly bridges the gap between classroom acquisitions and real-life context, thus allowing the learner to contextualize and adapt his skills to fit the labor market requirements. Similarly, factors like students' pre-acquisitions, students' number, and curriculum adequacy can influence TC development. Clearly, students with poor preacquisitions are unlikely to improve their skills as fast as those with considerable prior knowledge. In the same way, a poor or inadequate curriculum cannot provide students with the necessary skill. To compensate for students' deficiencies in domain, bilingual and bicultural competence, translation teaching programs should include courses that address other fields of knowledge relevant to translation.

The most important output of this study is that it yields a comprehensive overview of the different components of TC in relation to a compilation of teaching practices and objectives. It also reveals the general patterns that characterize teaching procedures and how they are related to students' levels of TC. Additionally, this study depicts these practices in their real environment and reports their objectives and teaching outcomes. However, this research has its unavoidable limitations. To start with, the size of the sample of teachers and the limited number of sessions observed were not enough to identify all the tasks and activities conducted in their classes. Another methodological constraint lies in the fact that data about students' TC levels were collected through self-report.

While the immediate aim of this study is to describe the different teaching procedures conducted by translation teachers and their role in developing TC, its outcomes may hopefully offer grounds for further research investigating other aspects of the topic. Certainly, a longitudinal study tracking TC development throughout a translation program would yield findings that are more accurate and comprehensive.

Funding: This research received no external funding.

Conflicts of Interest: The authors declare no conflict of interest.

\section{References}

[1] Albir, A. H. (2008). Competence en traduction et formation par compétences. TTR, 21(1), 17-64.

[2] Albir, A. H. (2015). The Acquisition of Translation Competence: Competencies, Tasks, and Assessment in Translator Training. Meta, 60(2), 256-280. doi:10.7202/1032857ar

[3] Albir, A. H. (Ed.). (2017). Researching Translation and Interpreting Competence by PACTE Group. Amsterdam-Philadelphia: John Benjamins

[4] Albir, A. H. (2020). Translation competence and its acquisition. The Routledge Handbook of Translation and Cognition, 389-414. https://doi.org/10.4324/9781315178127-26

[5] Baartman, L.K.J., \& de Bruijn, E. (2011). Integrating knowledge, skills, and attitudes: Conceptualizing learning processes towards vocational competence. Educational Research Review, 6, 125-134. doi:10.1016/j.edurev.2011.03.001

[6] Chomsky, N. (1968). Language and Mind. New York: Hartcourt Brace.

[7] Gonzalez-Davies, M. (2004). Multiple voices in the translation classroom: Activities, tasks, and project. Amsterdam: John Benjamins Publishing.

[8] Göpferich, S. (2009). Towards a model of translation competence and its acquisition: the longitudinal study TransComp. Copenhagen Studies in language, 11-37.

[9] Harris, B. \& Sherwood, B. (1978). Translating as an Innate Skill. In D. Gerber \& H. Sinaiko(Eds.), Language interpretation and communication. Oxford and New York: Plenum.

[10] Hodge, S. (2007). The origins of competency-based training. Australian Journal of Adult Learning, 47 (2), 179-209. https://files.eric.ed.gov/fulltext/EJ797578.

[11] Kelly, D.(2005). A handbook for translator trainers: A guide to reflective practice. Manchester: St Jerome.

[12] Kiraly, D. (2013). Towards a View of Translator Competence as an Emergent Phenomenon: Thinking Outside the Box(es) in Translator Education. In: Don Kiraly, Silvia HansenSchirra and Karin Maksymski, eds. New prospects and perspectives for educating language mediators (197-224). Tübingen: Gunter Narr. Retrieved from: https://www.researchgate.net/publication/286924040

[13] Krahnke, K. (1987). Approaches to syllabus design for foreign language teaching. Language in education: Theory and practice. Englewood Cliffs, New Jersey:

[14] Lasenier, F. (2001) Un modèle intégré pour l'apprentissage d'une compétence. Pédagogie collégiale,15(1). https://core.ac.uk/download/pdf/52977894.

[15] Neubert, A. (2000). Competence in language, in languages, and in translation. In C. Schäffner, \& B. Adab, (Eds.), Developing Translation Competence. Amsterdam / Philadelphia: Benjamins.

[16] Nida, E. A. (1981). Translators are Born Not Made. In E. Fry, (Ed.), Practical Papers for the Bible Translator,32(4)401-405.

[17] Nord, C. (2001). Training functional translators. In M. Tennent, (Ed.) In Training for the new millennium: Pedagogies for translation and interpreting (3-33). Amsterdam and Philadelphia: John Benjamins.

[18] PACTE. (2003). Building a translation competence model. In F. Alves (ed.), Triangulating Translation: Perspectives in process-oriented research. Amsterdam: John Benjamins.

[19] Richards, J.C. \& Rodgers, T. (2001). Approaches and methods in language teaching. Second Edition. New York: Cambridge University Press.

[20] Schäffner, C. \& Adab, B. (Eds.). (2000). Developing translation competence. Amsterdam / Philadelphia: Benjamins.

[21] Toury, G. (1995). Descriptive studies and beyond. Amsterdam: John Benjamins Publishing Company. 